\title{
A Comparative Anatomical Study of the Grapevine, Shoot and Cane: \\ II: Periderm and Secondary Phloem ${ }^{1}$
}

\author{
J. J. SWANEPOEL ${ }^{\mathrm{a}}$, A. C. DE LA HARPE ${ }^{\mathrm{a}}$, C. J. ORFFER
}

a) Viticultural and Oenological Research Institute (VORI), Private Bag X5026, 7600 STELLENBOSCH, Republic of South Africa.

b) Department of Viticulture, University of Stellenbosch, 7600 STELLENBOSCH, Republic of South Africa.

Submitted for publication: April 1984

Accepted for publication: August 1984

The authors wish to express their thanks to Miss. E. Pieters and Mrs. J. den Heijer for technical assistance.

\begin{abstract}
The taxonomic value of ten periderm and secondary phloem features of canes of different grapevine species was investigated. A scatter diagram showed that with few exceptions the American cultivars have a larger periderm with smaller secondary phloem, while the reverse was true for European cultivars. Crosses tend to cluster with one of their parents. It has been found that the largest intercultivar variation occurs at either the middle of the shoot length or the ventral sides of the basal part of the shoots.
\end{abstract}

\section{INTRODUCTION}

The importance of the periderm in taxonomic studies is shown by Esau (1965) in a study of 30 Vitis spp where a variation in depth of the position where periderm is formed was observed. This positional variation influence abscission of epidermis, cortex and varying quantities of secondary phloem. In Vitis spp other than Vitis rotundifolia $\mathrm{M}$., the deep position of the periderm is a well known fact (Kroemer, 1923; Esau, 1948a; 1965).

Taxonomic characteristics of the secondary phloem, the most studied tissue of Vitis (Esau, 1948a; 1948b; 1965) appear to be the total secondary phloem diameter, number of secondary phloem fibre bands (Esau, 1948b; Hegedüs, 1960), diameter of secondary phloem fibre bands, accumulation of starch and relative quantities of secondary parenchymatous phloem between the secondary phloem fibre bands (Kaszab, 1976). Variation in these characteristics has been shown between species (Plank \& Wolklinger, 1976; Navrotyskaya, 1980) and within species (Esau, 1965).

The object of this investigation was to determine the importance of peridermal and secondary phloem features in the classification of cultivars based on the anatomy of the cane.

\section{MATERIALS AND METHODS}

Material was collected and prepared as described by Swanepoel, de la Harpe \& Orffer (1983), and only canes sampled 24 weeks after bud break were used. The cultivars used are given in Table 1.

Characteristics: Three epiderm and seven secondary phloem features were employed (Table 2). Characteristics 3, 5, 6 and 7 were calculated with the aid of a digitizer directly connected to a mini-computer (HP 1000). Area,
TABLE 1

The genetic and geographical origin of experimental material

\begin{tabular}{|l|l|l|}
\hline Species Combination & \multicolumn{1}{|c|}{ Cultivar } & \multicolumn{1}{|c|}{ Geographical locality } \\
\hline Vitis champini $\mathrm{P}$. & Ramsey & Nietvoorbij, Stellenbosch \\
V. riparia M. & Riparia Gloire & Welgevallen, Stellenbosch \\
& de Montpellier & \\
V. rupestris S. & Rupestris du Lot & Welgevallen, Stellenbosch \\
V. vinifera $\mathrm{L}$. & Cape Riesling & Nietvoorbij, Stellenbosch \\
V. vinifera & Chenin blanc & Nietvoorbij, Stellenbosch \\
V. vinifera & Cinsaut & Nietvoorbij, Stellenbosch \\
V. vinifera & Colombar & Nietvoorbij, Stellenbosch \\
V. vinifera & Pinotage & Nietvoorbij, Stellenbosch \\
V. vinifera & Pinot noir & Nietvoorbij, Stellenbosch \\
V. berlandieri $\mathrm{P}$. & 99 Richter & Nietvoorbij, Stellenbosch \\
V. rupestris & 101-14 Mgt & Paradyskloof, Stellenbosch \\
V. riparia $\mathrm{X}$ & & \\
V.rupestris & & \\
\hline
\end{tabular}

TABLE 2

List of periderm and secondary phloem features employed

\begin{tabular}{|c|c|c|}
\hline Number & Characteristic & Unit \\
\hline${ }^{*} 1$ & Position of the first formed periderm: & \\
\hline & Outside primary phloem & \\
\hline & Border between primary and secondary phloem $: 2$ & \\
\hline & In secondary phloem & \\
\hline 2 & Number of peridermal cell layers & \\
\hline 3 & Radial diameter of periderm & $\mu \mathrm{m}$ \\
\hline 4 & Number of secondary phloem fibre bands & \\
\hline 5 & Area of secondary phloem fibre bands & $\mathrm{mm}$ \\
\hline 6 & $\begin{array}{l}\text { Area of secondary phloem fibre bands calculated as } \\
\text { percentage of the area between the secondary phloem } \\
\text { fibre bands. }\end{array}$ & \\
\hline 7 & Radial diameter of functional secondary phloem & $\mu \mathrm{m}$ \\
\hline 8 & Area of functional secondary phloem & $\mathrm{mm}$ \\
\hline 9 & $\begin{array}{l}\text { Median of radial diameter of periderm: median of } \\
\text { radial diameter of functional secondary phloem }\end{array}$ & \\
\hline 10 & $\begin{array}{l}\text { Median of radial diameter of functional secondary } \\
\text { phloem: Median of radial diameter of secondary zylem }\end{array}$ & \\
\hline
\end{tabular}

* Qualitative characteristic.

${ }^{1}$ Part of a M.Sc (Agric) thesis presented to the University of Stellenbosch. Promotor: Prof. C. J. Orffer 
given in $\mathrm{mm}^{2}$, was calculated by moving the digitizer along the circumference of the tissue, while the other measurements are given in $\mu \mathrm{m}$. The number of epidermal cell layers are the layers representing the phellogen, phelloderm and phellem.

Statistical analysis: The statistical analysis described by Swanepoel et al., (1983) was used in this study. Significance of differences between cultivars were shown by means of a factorial analysis based on Tukey's formula (Snedecor \& Cochran, 1967) and executed on the Burroughs 7800 computer of the Department of Agriculture.

Numerical analysis: The data were analysed using a batch process version of the pattern recognition system "Arthur" (Harper, Duewer \& Kowalski, 1977) and executed on the Univac 1100 computer of the University of
Stellenbosch. Subprogrammes employed were those described by Van Rooyen \& Tromp (1982) and De la Harpe \& Visser (1983).

\section{RESULTS AND DISCUSSION}

Position of the first formed periderm: A periderm was present in the cane of all the cultivars studied. A second periderm was occasionally formed on the ventral and dorsal sides of the basal zones of $V$. vinifera $\mathrm{L}$. cv. Pinot noir and 101-14 Mgt ( $V$. riparia $\mathrm{M} . \mathrm{x} V$. rupestris $\mathrm{S}$.) (Fig. 1). In the apical zones the first periderm was formed between the primary and secondary phloem whilst in the middle and basal zones, it was formed in different positions (depending on the cultivar) (Table 3).

TABLE 3

Values of periderm and secondary phloem features for the cane

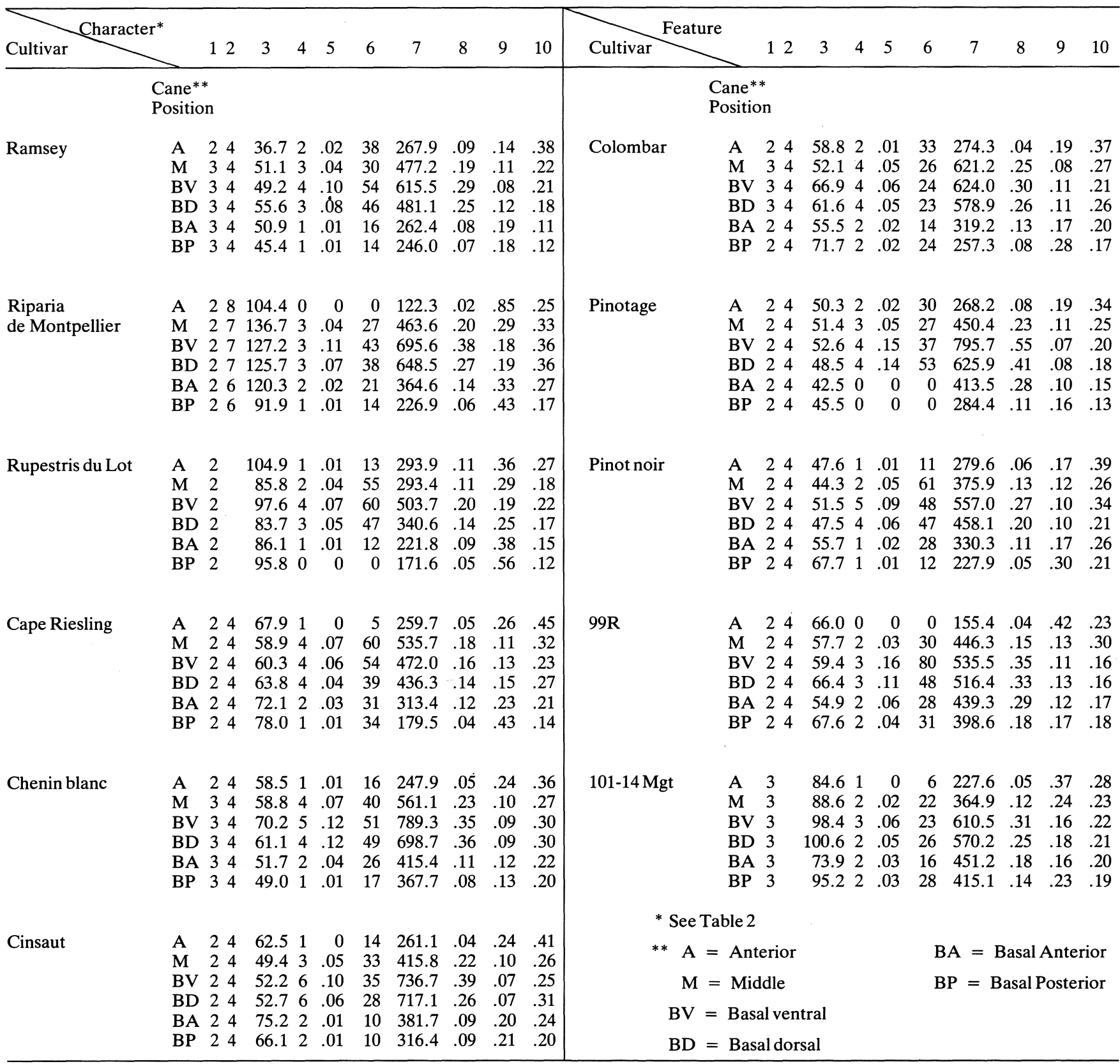




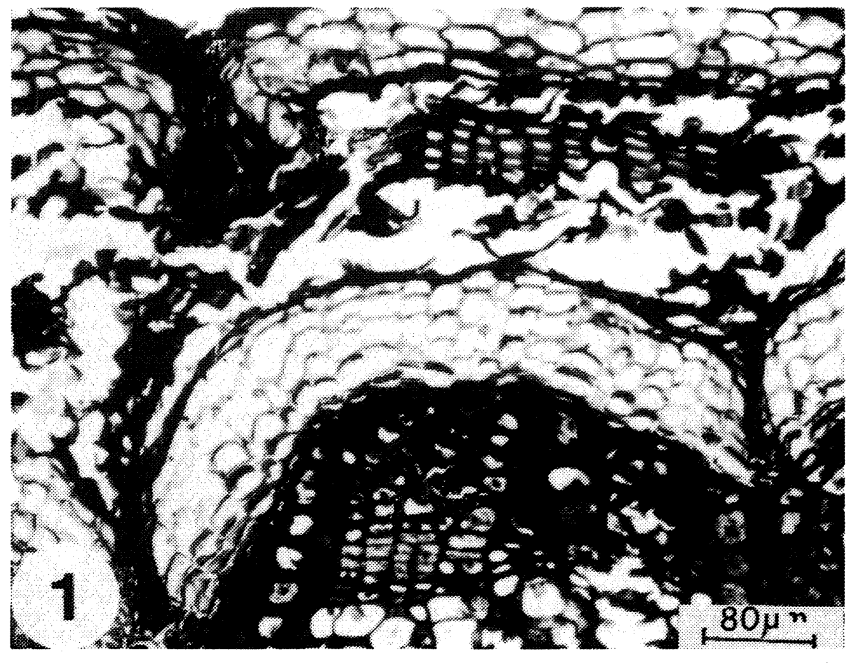

FIGURE 1

Cross-section through the basal zone of the cane of 101-14 Mgt ( $V$. riparia $\mathrm{x} V$. rupestris) illustrating the double periderm (p).

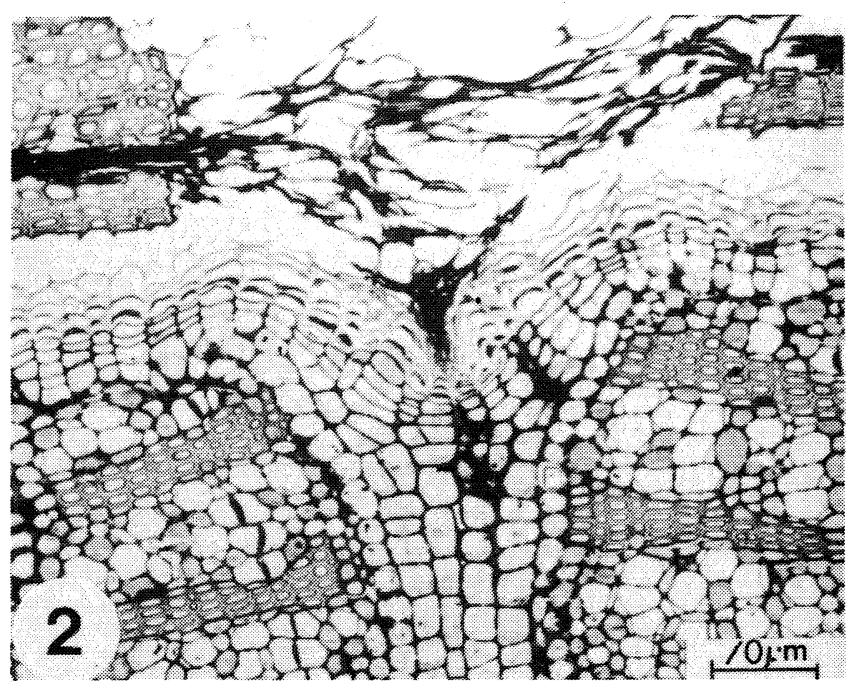

FIGURE 2

Cross-section through the middle zone of the cane of Ruspestris du Lot ( $V$. rupestris) illustrating the formation of periderm between the primary and secondary phloem.

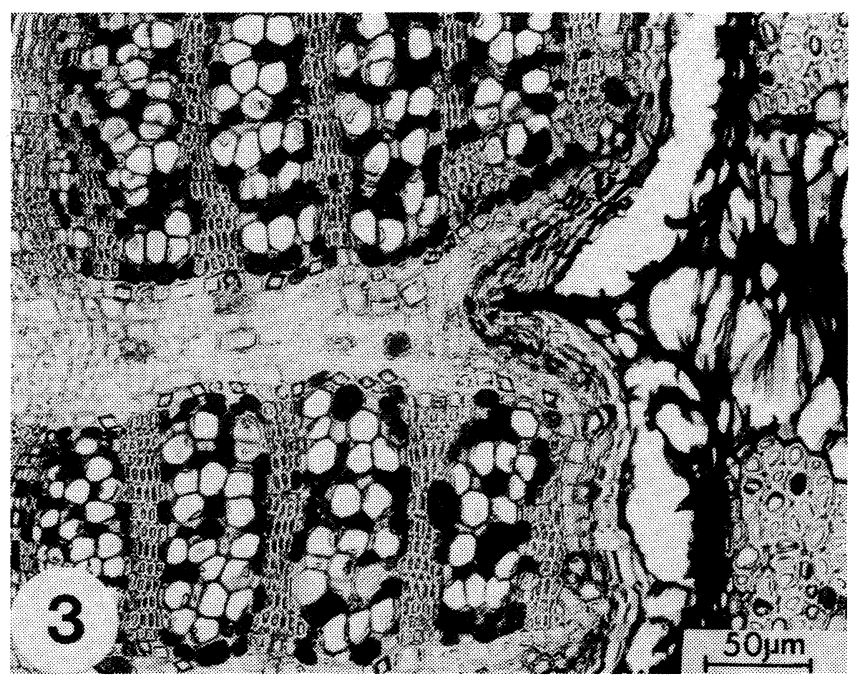

FIGURE 3

Cross-section through the middle zone of the cane of Ramsey ( $V$. champini) illustrating the deep seated periderm.
No definite tendencies concerning the depth of periderm formation were observed, but the two American cultivars representing $V$. rupestris and $V$. riparia had a similar formation of periderm, namely between the primary and secondary phloem (Fig. 2). In $V$. vinifera cvs. Colombar and Pinotage the periderm occurred either between the primary and secondary phloem or within the latter (Fig. 3).

Number of peridermal cell layers: Although Zilai, Tompa \& Scheuring (1973) noted no difference in the number of peridermal cell layers in different cultivars, this study showed that $V$. champini P. cv. Ramsey, $V$. vinifera cultivars and $99 \mathrm{R}(V$. berlandieri $\mathrm{P} . \mathrm{x} V$. rupestris) had four layers, $V$. rupestris $\mathrm{cv}$. Rupestris du Lot and 101-14 Mgt five and V. riparia cv. Riparia Gloire de Montpellier six to eight layers (Table 3 ).

Radial diameter of periderm: (Character 3; Table 3). From the data presented in Table 3 it is evident that the largest intercultivar variation, varying from $44,3 \mu \mathrm{m}$ (Pinot noir) to $135,7 \mu \mathrm{m}$ (Riparia Gloire de Montpellier), occurred in the middle zone of the cane. Taking into account all the positions on the cane, the diameter was significantly $(\mathrm{P} \delta 0,05)$ higher in Riparia Gloire de Montpellier, Rupestris du Lot and 101-14 Mgt than in the other cultivars. With respect to the four sides of the basal zone the largest variation was observed in 101-14 Mgt (standard deviation $(\sigma=12,31)$ while Ramsey $(\sigma=4,23)$ had the smallest variation.

Number and area of secondary phloem fibre bands: With respect to the middle zone marked secondary phloem fibre formation could be observed in the canes of the $V$. vinifera cultivars. These fibres form broad bands which vary in number from 0 to 6 in the canes of Riparia Gloire de Montpellier and $V$. vinifera $\mathrm{cv}$. Cinsaut (Table 3). In the cane of eg. Ramsey the number of bands are restricted by the deep seated periderm, which cut off a considerable amount of secondary phloem including bands of phloem fibres. In the basal zones the number of bands was the highest on the ventral sides (3) and lowest in the posterior sides (2). A large intercultivar variation concerning the number of bands on the four sides of the basal zone occurs (Fig. 4) with 99R and 101$14 \mathrm{Mgt}$ the only cultivars having approximately the same number of bands on all 4 sides

When the secondary phloem fibre band area is calculated as a percentage of the area of the secondary phloem situated between these bands, it is evident that Riparia Gloire de Montpellier and 101-14 Mgt have the smallest and $V$. vinifera $\mathrm{cv}$. Cape Riesling the largest secondary phloem fibre bands at each individual zone of the cane (Table 3). A similar tendency was observed when calculated as a percentage of the total secondary phloem area. Significant differences occurred in the canes of the investigated cultivars with respect to the size of the functional secondary phloem (Table 3). Similar differences between $V$. vinifera-cultivars were observed by Esau (1948a).

The largest intercultivar variation $(\sigma=100)$ was observed on the ventral side of the basal zone where the radial diameter varies from $472,0 \mu \mathrm{m}$ (Cape Riesling) to $795,7 \mu \mathrm{m}$ (Pinotage). As far as the basal zone of the canes are concerned largest values were observed on the ventral sides and the smallest on the posterior sides. Similar results concerning the radial diameter of the secondary phloem were found in that Cape Riesling has the smallest and Pinotage the largest area (Table 3).

However, in order to exclude the variations in the 

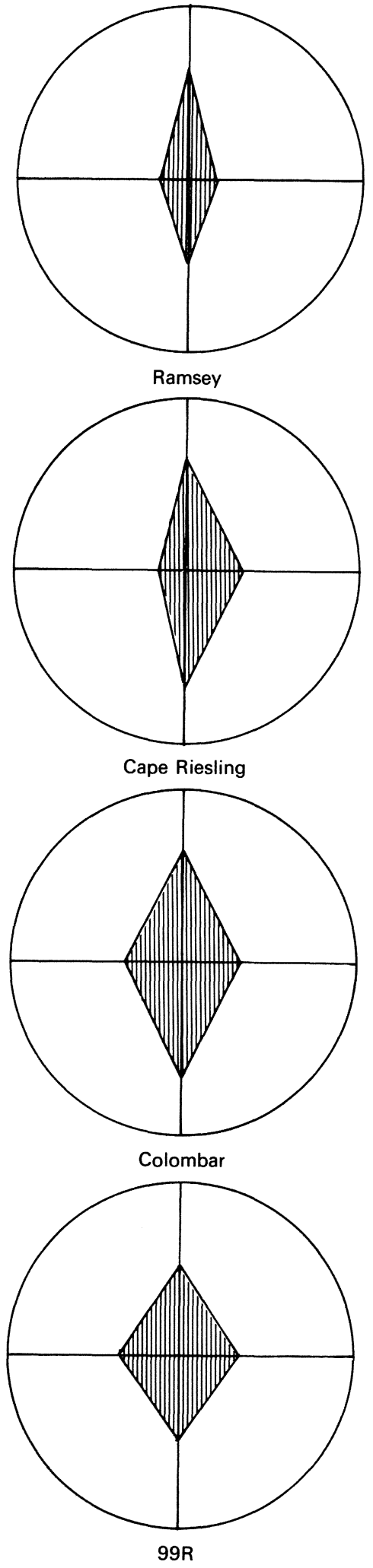

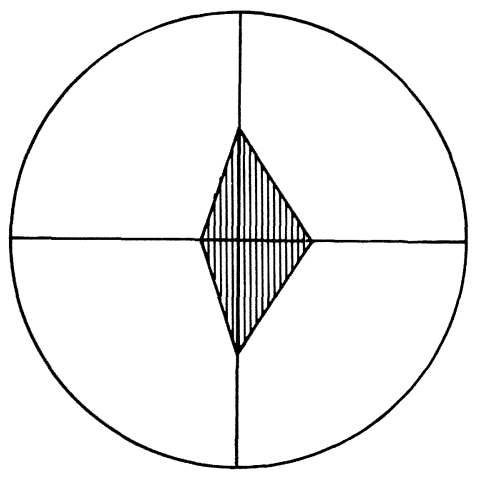

Riparia Gloire de Montpellier
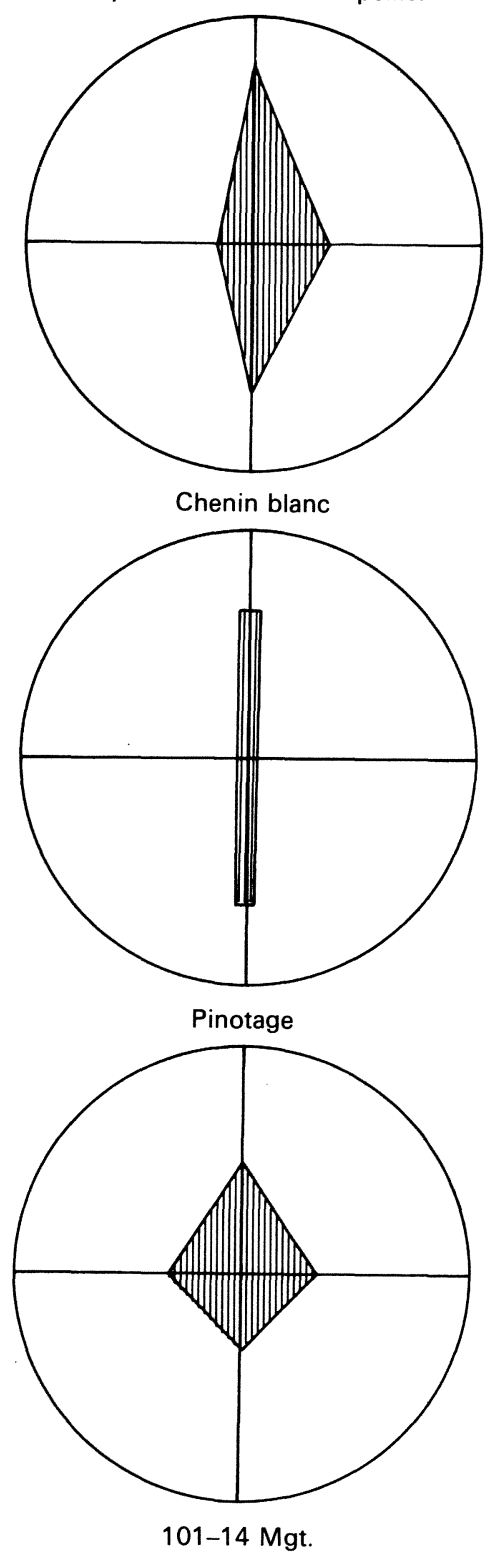

FIGURE 4

Graphs indicating the variation in number of secondary phloem fibre bands on the 4 sides of the basal zone of the canes of the Vitis spp. studied.
$\mathrm{V}=$ Ventral
$\mathrm{A}=$ Anterior
$\mathrm{D}=$ Dorsal
$\mathrm{P}=$ Posterior
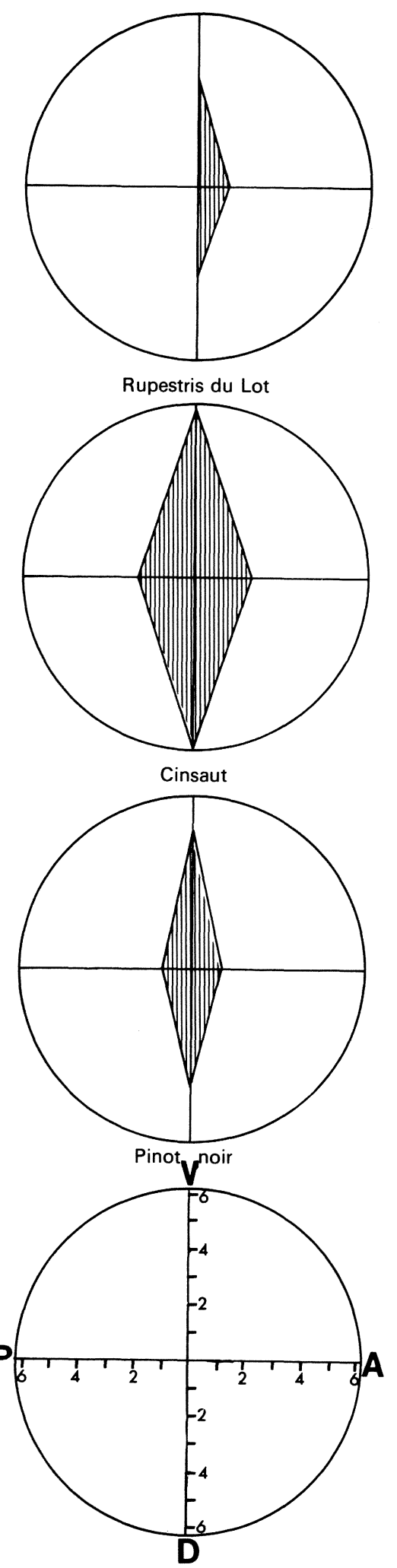
thickness of the examined canes, the thickness of the functional secondary phloem is specified as the ratio between the thickness of this tissue and either the radial diameter of the periderm or the radial diameter of the secondary xylem. For a specific zone on the cane the periderm: secondary phloem ratio appears to be constant between the cultivars but within a cultivar a large variation over different cane positions is observed. A small intracultivar variation $(\sigma=0,061)$ concerning the middle zone and ventral and dorsal sides of the basal zone do occur. With the exception of Cape Riesling, a small intercultivar variation $(\sigma=0,075)$ exists between $V$. vinifera cultivars, Ramsey and 99R. These cultivars differ significantly from the other cultivars studied.

From the secondary phloem: secondary xylem ratio (Table 3 ) it is evident that $V$. vinifera-cultivars have a strikingly broad secondary phloem whilst Riparia Gloire de Montpellier has a small functional secondary phloem. Numerical analysis: After the subroutine "SELECT" of the Pattern Recognition System "ARTHUR" (Harpet et al., 1977), was executed on all the characteristics, periderm and secondary phloem characteristics were indicated as playing the most important part in identifying species and/or cultivars (Swanepoel, 1983). A plot of these features for the middle zone of the cane is given in Fig. 5, from which it can be seen that with the exception of Pinot noir all the $V$. vinifera spp. were clustered in one group, while this was not the case with the American cultivars.

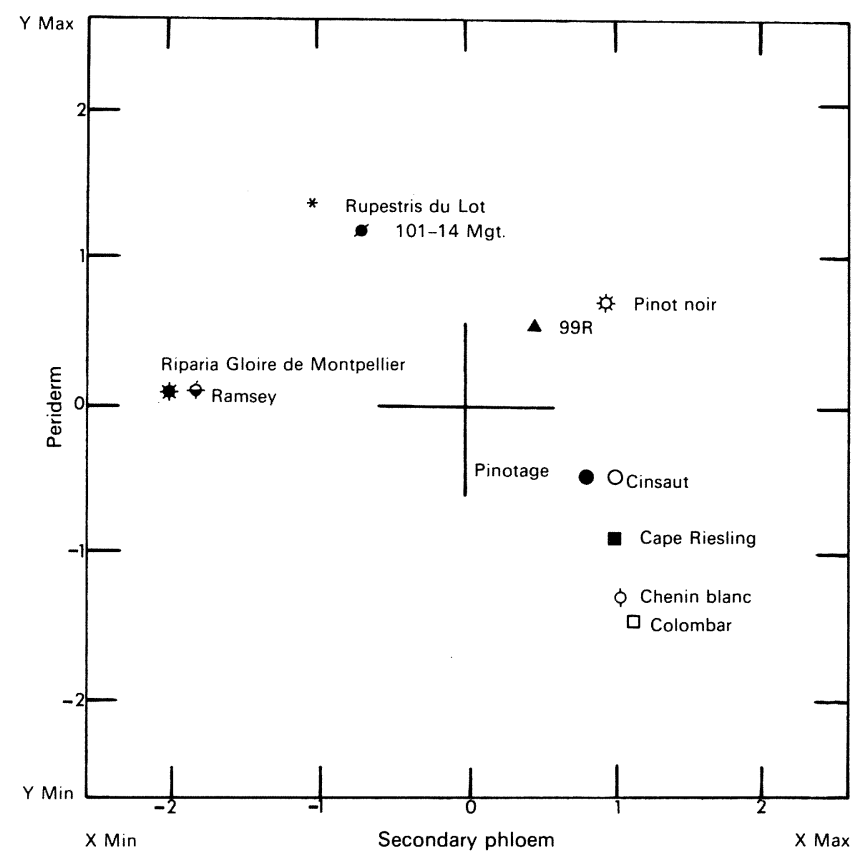

FIGURE 5

Scatter diagram illustrating the ordination of Vitis cultivars in the middle zone of the cane.

From this it can be concluded that the American species tend to have larger periderm but smaller phloem features whilst in the case of European species the opposite tends to be true. Furthermore, crosses tend to cluster with one of their parents (Pinotage and 101-14 Mgt). Similar results were shown by Schilling \& Heiser (1976) with different Solanum spp and crosses.

These results indicated that $V$. berlandieri, parent of
99R, tends to have a closer resemblance to $V$. vinifera than to American species. With respect to the anatomy of roots of Vitis, Mazoni (1952) and Pongracz \& Beukman (1970) showed that $V$. berlandieri has features which correspond with those of $V$. vinifera.

\section{CONCLUSIONS}

The results indicate that with the aid of the anatomical characteristics of the secondary phloem and periderm the examined cultivars can be distinguished from one another and therefore these characteristics are of taxonomic value. In a scatter diagram where periderm characteristics were plotted against secondary phloem characteristics a distinct clustering, with the exception of Pinot noir, of all the $V$. vinifera samples in one group was observed, while this was not the case with the American cultivars. Crosses tend to cluster with one of their parents.

It was found that the largest intercultivar variation occurs at either the middle zone or the ventral sides of the basal zone, indicating that in future studies, only these zones need to be studied.

\section{LITERATURE CITED}

DE LA HARPE, A. C. \& VISSER, J. H., 1983. The determination of the homogeniety of a Vitis vinifera L. cv. Cape Riesling vineyard. In press.

ESAU, K., 1948a. Phloem structure in the grapevine and its seasonal changes. Hilgardia. 18, 217-296.

ESAU, K., 1948b. Anatomic effects of the virusses of Pierce's disease and phony peach. Hilgardia. 18, 423-482.

ESAU, K., 1965. Anatomy of cytology of Vitis phloem. Hilgardia, 37, $17-72$.

HARPER, A. M., DUEWER, D. L. \& KOWALSKI, B. R., 1977. Arthur and Experimental Data Analysis: The heuristic use of a polyalgorithm documentation for Arthur, Version 1-9-77. Laboratory for Chemometrics. Dept. of Chemistry. Univ. Georgia, Athens, Georgia.

HEGEDÜS, A., 1960. Conclusions phylogénétiques relatives à la structure histologique de la vigne. Megy. Fud. Adad. Bot. Közlem. 6, 257-266.

KASZAB, L., 1976. Histological characterization of some grapevine cultivars based on studies of the ventral side of one-year-old shoots. Kertész. Egeyt. Köz. 39, 409-419.

KROEMER, K., 1923. Organographie, Anatomie und physiologie der Rebe. In von Babo, F. \& Mach, E. Handbuch des Weinbaues und der Kellerwirtschaft. Paul Parey, Berlin.

MANZONI, G., 1952. Conziderazioni su differenze anatomiche in radici di barbatelli di Vitis vinifera, $V$. riparia, $V$. rupestris, $V$. berlandieri. Ann. Sper. Agr. 7, 299-337.

NAVROTSKAYA, A. A. 1980. Anatomical characteristics of grape varieties VII. Vinograd, Odessa 14-20.

PLANK, S. \& WOLKLINGER, F., 1976 Hölz von Vitis vinifera im rasterelektronen-mikroskop. Vitis 15, 153-159.

SCHILLING, E. E. Jr. \& HEISER, C. B. . Jr. . 1976. Re-examination of a numerical taxonomic study of Solanum species and hybrids. Taxon 25, 451-462.

SNEDECOR, G. W. \& COCHRAN. W. C., 1967. Statistical Methods. 6th Ed. The Iowa State University Press, Ames.

SWANEPOEL, J. J., 1983. 'n Vergelykende anatomiese studie met internodia van wingerdlote van onderskeie wingerdcultivars (Vitis spp.). M.Sc. thesis, Univ. Stellenbosch.

SWANEPOEL, J. J., DE LA HARPE, A. C. \& ORFFER, C. J., 1983. A comparative anatomical study of the grapevine, shoot and cane: I. Epidermis, of the shoot. (In Press.)

VAN ROOYEN, P. C. \& TROMP, A.. 1982. The effect of fermentation time (as induced by fermentation and must conditions) on the chemical profiles and quality of a Chenin blanc wine. S. Afr. J. Enol. Vitic. 3, 75-80.

ZILAI, J., TOMPA \& SCHEURING, M. . 1973. Histological studies for determining the maturity of grapevine propagation material. Kertész. Egeyt. Köz., 36, 39-50. 